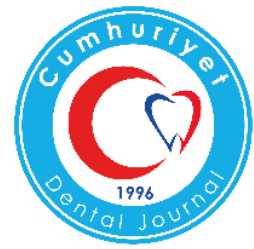

\title{
INVESTIGATION OF CYTOTOXIC EFFECTS OF EUGENIA CARYOPHYLLUS (CLOVE)
}

\author{
Eugenia Caryophyllus (Karanfil) 'un Sitoksisitesinin Araştırılması
}

\author{
Ceylan HEPOKUR ${ }^{1}$
}

\begin{tabular}{ll} 
Makale Kodu/Article Code & $: 444426$ \\
Makale Gönderilme Tarihi & $: 17.07 .2018$ \\
Kabul Tarihi & $: 26.07 .2018$ \\
\hline
\end{tabular}

\section{ABSTRACT}

Objectives: Eugenia caryophyllus clove has been used as a traditional medicinal herb for thousands of years. It is used as an analgesic for tooth and toothache with the effect of eugenol substance included in clove. Eugenia caryophyllus is used at toothpaste and some mouthwash. The aim of this study was determined of in vitro cytotoxic effects Eugenia caryophyllus on fibroblast cells.

Materials and Methods: Cytotoxic activity of Eugenia caryophyllus were incubated at 24 and $48 \mathrm{~h}$.

Results: In the present study, toxicity of clove that is used as a pain reliever in dentistry has examined on fibroblast cells. The $\mathrm{IC}_{50}$ values of Eugenia caryophyllus were found $57.92 \pm 0.98 \mu \mathrm{g} / \mathrm{mL}$ in 24 $\mathrm{h}, 37.97 \pm 0.74 \mu \mathrm{g} / \mathrm{mL}$ in $48 \mathrm{~h}$.

Conclusions: It is found that the acceptable level of cytotoxicity of Eugenia caryophyllus. There is need to further studies in this area.

Keywords: Eugenia caryophyllus, Cytotoxicity, Cell culture

\section{ÖZ}

Amaç: Eugenia caryophyllus binlerce yıldır geleneksel şifalı bitki olarak kullanılmaktadır. Karanfil içerisindeki öjenol maddesinin etkisi ile diş ve diş ağrıları için analjezik olarak kullanılır. Karanfil, diş macunu ve bazı gargaralarda kullanılmaktadır. Bu çalışmanın amacı Eugenia caryophyllus in vitro sitotoksik etkileri fibroblast hücre hatları üzerinde belirlemiştir.

Gereç ve Yöntem: Eugenia caryophyllus'un sitotoksik aktivitesi XTT testi kullanılarak değerlendirildi. Eugenia caryophyllus 24 ve 48 saatlerde inkübe edildi.

Bulgular: Bu çalışmada diş hekimliğinde ağrı kesici olarak kullanılan karanfil toksisitesi fibroblast hücreleri üzerinde incelenmiştir. Eugenia caryophyllus'un $\mathrm{IC}_{50}$ değerleri 24 saat de 57,92 \pm $0,98 \mu \mathrm{g} / \mathrm{mL}, 48$ saatte de $37,97 \pm 0,74 \mu \mathrm{g} / \mathrm{mL}$ olarak bulundu.

Sonuç: Eugenia caryophyllus'un kabul edilebilir düzeyde sitotoksisitesinin olduğu bulunmuştur. $\mathrm{Bu}$ alanda daha ileri çalışmalara ihtiyaç vardır.

Anahtar kelimeler: Eugenia caryophyllus, Sitotoksisite, Hücre kültürü

\footnotetext{
${ }^{1}$ Cumhuriyet University, Faculty of Pharmacy, Department of Basic Pharmaceutical Sciences, Division of Biochemistry, Sivas, Turkey
} 


\section{INTRODUCTION}

Nowadays, the extraction and evaluation of pure and especially main active component of medical plants and essential oils of these plants is very important both in scientific and in terms of economy. ${ }^{1}$ The pharmacological properties of essential oil and its components are also examined and it is stated that they may be beneficial in medicine, cosmetics and industrial areas. ${ }^{2}$ Essential oils are used in medicine from ancient times to the day. The use of herbal extracts for treatment of various human diseases has a long history. The abuse potential of herbal products causes serious side effects. As a result of pharmacological investigations on these medicines based on their intended use in folk medicine, some biological effects have been scientifically explained. Clove is a spice obtained from Syzygium aromaticum tree. ${ }^{3}$ Cloves can also be used by being kept in the mouth for a while, and also used as a spice. it keeps your breath fresh and clean. Cloves are used extensively against bad breath due to their beautiful smell. Cloves contain $15-20 \%$ volatile, $13 \%$ tannin, $10 \%$ fixed oil. Eugenol is major component of clove oil. The effect of "eugenol" contained in it is used as a local drug against mild to moderate dental and gingival pain. ${ }^{4}$ In addition, eugenol has antiviral and antimycotic effects. Cloves contain 15-20\% volatile, $13 \%$ tannin, 10\% fixed oil. Flower buds and flower stalks are dried and used. Eugenol obtained from carnauba is used as antiseptic and analgesic in modern dentistry. ${ }^{5}$ Its use is in the mouth chewing or their beans are boiled in water and drink. Cloves are frequently used in dentistry. The aim of this study was assessment of in vitro cytotoxic effects Eugenia caryophyllus on fibroblast cells.

\section{MATERIALS AND METHODS}

\section{The Reagent}

Phosphate buffer saline (PBS) tablet, trypan blue solution, dimethyl sulfoxide (DMSO), XTT assay and another chemical were purchased from Sigma (St. Louis, MO, USA). Fetal bovine serum (FBS) was obtained from Biochrom (Berlin, Germany). Penicillin-streptomycin was purchased from Gibco (Paisley, UK) and trypsin EDTA solution from Biological Industries (Kibbutz Beit Haemek, Israel). Dulbecco's modified eagle medium (DMEM) was obtained from Lonza (Verviers, Belgium).

\section{Eugenia caryophyllus (Clove) Oil}

Eugenia caryophyllus essential oil was used in the study. Eugenia caryophyllus essential oil was purchased from Art de Huile.

\section{Cell Culture}

Mouse fibroblast (ATCC-CRL-6364) cells were purchased from (ATCC). Cells were grown at $37^{\circ} \mathrm{C}$ in a humidified incubator in $5 \%$ $\mathrm{CO}_{2}$. All media were supplemented with $1 \%$ penicillin $(100 \mathrm{U} / \mathrm{mL})$ and streptomycin $(100$ $\mu \mathrm{g} / \mathrm{mL}$ ), and $10 \%$ fetal bovine serum (FBS). Cells were counted by a cell counting device (Olympus). Fibroblast cells were seeded in plates with a density of $5 \times 10^{3}$.

\section{Cytotoxicity Assay}

Cytotoxicity was quantitatively evaluated by the 2,3-bis-(2-methoxy-4-nitro-5-sulfophenyl)-2Htetrazolium-5-carboxanilide (XTT) method. The cells were seeded in 96-well plate in growth medium then treated with different concentrations of test compounds and incubated in a humidified $\mathrm{CO}_{2}$ atmosphere at $37^{\circ} \mathrm{C}$ for 24 and $48 \mathrm{~h}$. After the incubation, $100 \mu \mathrm{L}$ XTT was added to each well for another $2 \mathrm{~h}$ incubation. The optical density values were measured at $475 \mathrm{~nm}$ with a microplate reader. ${ }^{6}$ The all cells were treated with Eugenia caryophyllus (Clove) $(200-6.25 \mu \mathrm{g} / \mathrm{mL})$, and incubated for $24 \mathrm{~h}$ and $48 \mathrm{~h}$. All absorbance was compared to control samples (cells without any test compound) which represented $100 \%$ viability. Cell viability was determined as in Eq1.

Cell viability $(\%)=\frac{[\text { ODsample }- \text { ODblank }]}{[\text { ODpozitifcontrol-ODblank }]} \times 100$ (Equation 1)

OD blank: dead cell with DMSO

OD positive control: viable cell 


\section{Statistical analysis}

Data were expressed in the form of arithmetic mean \pm standard deviation $(x \pm S D)$. Statistical analysis was performed with Sigma Plot 12.0. All determinations were computed independent triplicated $(n=3)$.

\section{RESULTS}

The cytotoxic effects of Eugenia caryophyllus in fibroblast cells are shown in Figure 1 and 2. Eugenia caryophyllus were studied at two different incubation times of $24 \mathrm{~h}$ and $48 \mathrm{~h}$. The IC50 values of Eugenia caryophyllus (Clove) were found $57.92 \pm 0,98 \mu \mathrm{g} / \mathrm{mL}$ in $24 \mathrm{~h}, 37.97 \pm$ $0.74 \mu \mathrm{g} / \mathrm{mL}$ in $48 \mathrm{~h}$.

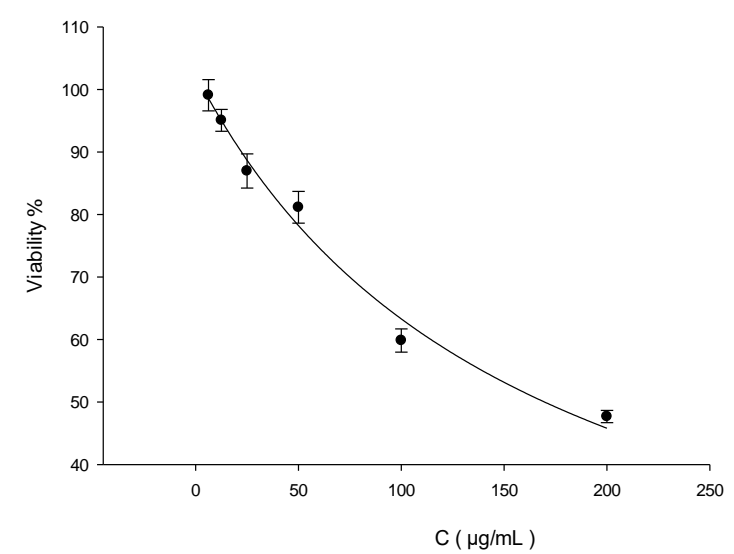

Figure 1. Cytotoxic effect of different concentrations of Eugenia caryophyllus in fibroblast cells for $24 \mathrm{~h}(\mathrm{n}=3)$.

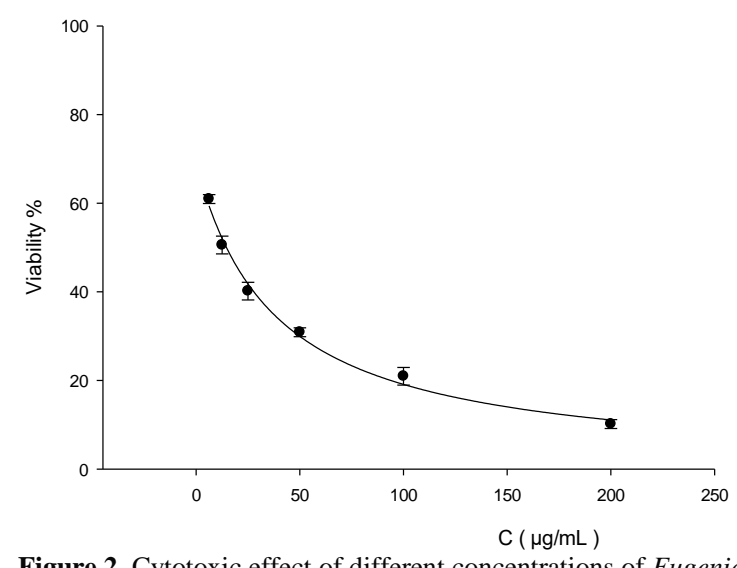

Figure 2. Cytotoxic effect of different concentrations of Eugenia caryophyllus in fibroblast cells for $48 \mathrm{~h}(\mathrm{n}=3)$.

\section{DISCUSSION}

Compounds of natural product in play an essential role in human life, acting as healthprotecting agents. Scientists have always been interested to active compounds of natural sources. Natural products are an extremely important resource for medical agents. However, although a new approach to drug discovery emerges day by day, none of them is as important as the place of natural products in drug development. ${ }^{7,8}$

Cloves has biological activities such as antibacterial, antifungal, insecticidal, antioxidant properties. And also, cloves have been used as flavoring and antimicrobial agents in food industries. ${ }^{9-10}$ Clove oil strengthens the immune system as it is a source of iron, calcium and omega3 ${ }^{11}$ Strong biological activities of the clove oil is mostly due to the presence of eugenol in high levels. In ancient times clove oil and dry carnation seeds were used to treat infection.

Because of anti-inflammatory effect is directly used in toothache and before mucosal injection by dentists. Oral ulcers such as oral gingiva and mucosal areas are also added to the mixtures as antimicrobial and analgesic. Clove used against mouth odor are used as a natural solution in removing dental pain. It is used as a drug against dental and gingival pain of mild to moderate severity with the effect of eugenol substance contained in clove. This material is also found in toothpastes for killing bacteria. It also has pain killer and germicidal properties. ${ }^{12}$

According to the GC-MS results of Cloves in the studies conducted when the literature was examined; Results showed that the extracts were complex mixture of numerous compounds; many of which were present in trace amounts. The concentration of eugenol varies from $77-95 \% .{ }^{13-14}$ Other studies of Eugenia caryophyllus was investigated for cytotoxicity; Tragoolpua and Jatisatienr stated that strains or isolates of viruses may affect the range of inhibition by Eugenia caryophyllus. ${ }^{15}$ Prashar et al. Clove oil and these components are generally recognized as 'safe', but the invitro study here demonstrates cytotoxic properties of both the oil and eugenol, towards human fibroblasts and endothelial cells. Clove 
oil was found to be highly cytotoxic at concentrations as low as $0.03 \%(\mathrm{v} / \mathrm{v})$ with up to $73 \%$ of this effect attributable to eugenol. ${ }^{16}$ Machado et al., S. aromaticum essential oil and eugenol did not caused a significant alteration on the viability of treated mammalian cells when compared to control cells. Our results compare to literature, cytotoxicity of clove has showed lower.

\section{CONCLUSION}

The acceptable level of cytotoxicity associated with Eugenia caryophyllus. It is seen that the effect of many natural substances such as cloves on cytotoxicity should be examined. Such studies will help to reveal substances that can be used naturally for humanity. We will try to expand this work in our next publication. Eugenia caryophyllus oil may use active substance for medicine.

\section{REFERENCES}

1. Toroğlu S. ve Çenet M. KSÜ Fen ve Mühendislik Dergisi. 2006; 9(2):12-20.

2. Hammer KA, Carson CF, Riley TV. Journal of Applied Microbiology.1999;86: 985-990.

3. Cortés-Rojas DF, Souza CRF, Oliveira WP. Clove (Syzygium aromaticum): a precious spice. Asian Pac J Trop Biomed. 2014;4(2): 9096.

4. Cansian RL, Vanin AB, Orlando T, Piazza SP, Puton BM, Cardoso RI, Gonçalves IL, Honaiser TC, Paroul N, Oliveira D. Toxicity of clove essential oil and its ester eugenyl acetate against Artemia salina. Braz J Biol. 2017; 77(1):155-161. doi: 10.1590/1519-6984.12215.

5. Mahmoud H, Mina KA, Hassan R. Analgesic effect of clove essential oil in mice. Avi J Phytomed. 2011;1:1-6.

6. Gezegen H, Hepokur C, Tutar U, Ceylan M. Synthesis and Biological Evaluation of Novel 1-(4-(Hydroxy (1-oxo-1,3-dihydro-2H-inden2-ylidene) methyl) phenyl) -3-phenylurea
Derivatives. Chemistry Biodiversity. 2017;14 (10): doi: 10.1002/cbdv.201700223.

7. Heinrich M, Bremner P. Ethanobotany and ethanopharmacy-their role for anticancer drug development. Curr Drug Targets. 2006; 7: 239245.

8. Thirumal M, Kishore G, Prithika R, Das S, Nithya G. In vitro anticancer activity of Tecoma stans (L) ethanolic leaf extract on human breast cancer. Journal of Pharmacognosy and Phytochemistry. 2016; 5(4): 331-334.

9. Jasna I, Suzana DB, Dusan M, Mihailo R, Irena Z. Evaluation and improvement of antioxidant and antibacterial activities of supercritical extracts from clove buds. J Funct Food. 2013;5:416-423.

10.Nazrul IB, Jaripa MD, Nemai CN, Farhana A. Constituents of the essential oil from leaves and buds of clove (syzigium caryophyllatum L. Alston). African J Plant Sci. 2010;4:451454.

11.Bressler K, Ron B. Effect Of Anesthetics On Stress And The Innate Immune System Of Gilthead Seabream (Sparus Surata), The Israeli. Journal of Aquaculture Bamidgeh.2014; 56(1):5-13.

12.Ho YC ,Huang FM, Chang YC. Mechanisms of cytotoxicity of eugenol in human osteoblastic cells in vitro. Int Endod J. 2006; 39(5):389-393.

13.Trajano VN, Lima EO, Souza EL, Travassos AER. Inhibitory effect of the essential oil from Eugenia caryophyllata Thumb leaves on coalho cheese contaminating microorganisms. Ciência e Tecnologia de Alimentos. 2010;30(4):10011006.

14.Singh J, Baghotia A, Goel SP. Thunberg (Family Myrtaceae): a review.Eugenia caryophyllata International Journal of Research in Pharmaceutical and Biomedical Sciences. 2012;3(4):1469-1475.

15.Tragoolpua Y, Jatisatienr A. Anti-herpes simplex virus activities of Eugenia caryophyllus (Spreng.) Bullock \& S. G. 
Harrison and essential oil, eugenol. Phytotherapy research. 2017;21(12):1153-58.

16.Prashar A, Locke IC, Evans CS. Cytotoxicity of clove (Syzygium aromaticum) oil and its major components to human skin cells, Cell Proliferation. 2006;39(4):241-248.

17. Machado M, Dinis AM, Salgueiro L, Custódio José BA, Cavaleiro C, Sousa MC. Anti-Giardia activity of Syzygium aromaticum essential oil and eugenol: Effects on growth, viability, adherence and ultrastructure. Exp Parasitol. 2011;127:732-739.

\section{Corresponding Author}

Ceylan HEPOKUR

Cumhuriyet University,

Faculty of Pharmacy,

Department of Basic Pharmaceutical Sciences, Division of Biochemistry

58140, Sivas, Turkey

Tel : : +903462191010 ext 3913

Fax : :903462191634

E-mail : cozsoya@gmail.com 